\title{
Adam Leszczyński, Ludowa historia Polski
}

\author{
Wydawnictwo WAB, Warszawa 2020, 669 ss.
}

https://doi.org/10.19195/1643-0328.29.12

Pisanie recenzji jest częścią aktywności zawodowej pracownika naukowego, która jest traktowana jako obowiązek, nie zawsze będący źródłem satysfakcji. Piszemy recenzje prac magisterskich, doktorskich czy habilitacyjnych, wykonując swoje powinności zawodowe. Niezwykle zaś rzadko zdarza się recenzowanie prac, które jest przyjemnością. Z taką sytuacją mamy do czynienia w odniesieniu do dzieła Adama Leszczyńskiego Ludowa historia Polski. Jest to praca, która wzbudza w recenzentce emocje. I jest to deklaracja, która nie powinna mieć miejsca. A jednak - po lekturze książki nie można na chłodno, z dystansem ocenić jej treści i formy. Zapewne wynika to z faktu, że recenzentka podziela punkt widzenia autora oraz odczuwa pewien rodzaj zazdrości, że opisał on coś, co nie jest oczywiste i idzie wbrew powszechnym mniemaniom czy osądom. Książka Adama Leszczyńskiego jest niezwykle ważna, nie będzie przesadą stwierdzenie, że jest przełomem w myśleniu o dziejach Polski. Dotychczasowa narracja prowadzona była z perspektywy władzy, szlachty, arystokracji, inteligencji, mieszczaństwa. Dzieje Polski opisywane były przez pryzmat elit, zrywów narodowych, kultury duchowej, martyrologii narodu (czytaj: szlachty), poetów, inteligencji. Książka Leszczyńskiego pokazuje nową perspektywę, którą dostrzegamy bardziej intuicyjnie niż racjonalnie. Historia Polski to niekoniecznie historia rodu Jurewiczów, Mycielskich, Zamoyskich, Czartoryskich itp. To nie jest wizja Polski z perspektywy Andrzeja Frycza Modrzewskiego, Piotra Skargi czy Hugona Kołłątaja. Autorka recenzji jest admiratorką Chłopów, powieści, którą czyta permanentnie, stąd też recenzowaną pracę naukową uważa za zracjonalizowaną wizję przeszłej Polski, którą literacko opisał Reymont.

Lekturę Ludowej historii Polski recenzentka rozpoczęła od ostatniego rozdziału. I jest to zabieg świadomy, gdyż autor prezentuje w nim założenia metodologiczne. Z punktu widzenia opisu naukowego określenie własnego instrumentarium badawczego jest sprawą niezwykle ważną. Nie fetyszyzując metodologii (z czym często mamy do czynienia we współczesnej nauce polskiej), należy uznać, iż zaprezentowanie własnej perspektywy badawczej jest kluczowe dla zrozumienia narracji. U podstaw pracy leży założenie o ciągłości historii, o długim trwaniu, przywołując termin Ferdynanda Braudela. W Eseju o metodzie Adam Leszczyński przytacza opinie i teorie z obszaru historii, zarówno polskie, jak i obce, ale nie zapomina o marksistowskiej historiozofii, która przecież mocno koncentrowała się na sprawach ludu. Daje przegląd prac historyków po 1989 roku, 
wskazując na ich zalety, ale także ułomności. Wniosek jest taki, że praca badacza dziejów jest obarczona wskazaniami ideologicznymi i zapotrzebowaniem bieżącej polityki. Nie ma w tym nic odkrywczego i autor także przyjmuje swoją perspektywę opisu historii Polski, zapewne zakotwiczoną we własnym systemie wartości i wizji świata. Powstaje jednakowoż pytanie: dlaczego wcześniej badacze przeszłości Polski nie zechcieli pójść tym tropem. Przyjmując, że możemy tworzyć narrację historyczną z perspektywy konserwatywnej, nacjonalistycznej czy marksistowskiej, dlaczego pomijano pisanie historii z perspektywy „ludowej”? Adam Leszczyński zdecydowanie odrzuca dziewiętnastowieczny sposób uprawiania historii, opierający się na sprawozdaniu ze źródeł oraz taki opis przeszłości, który ma utwierdzać dumę narodową i budować dobre samopoczucie. Odrzuca mit wielkiej Polski czy wręcz mit narodu wybranego, zwłaszcza że kategoria narodu nie może być stosowana na przykład w czasach Piastów, w późniejszych zaś okresach naród to tylko szlachta. Książka jest „historią 90 proc. społeczeństwa [...]” ( s. 569) - to bardzo znacząca deklaracja, która według recenzentki jest fundamentalna, gdyż autor uznaje, że to nie człowiek jest dla państwa, ale państwo dla człowieka. Stwierdzenie to $\mathrm{z}$ pozoru tylko jest banalne, $\mathrm{w}$ istocie cała spuścizna piśmiennicza polskich historyków, koncentruje się na państwie. Dokładniej rzecz ujmując - państwo jest wartością nadrzędną, by nie powiedzieć wartością samą w sobie. Dotyczy to nie tylko historii okresu rozbiorów. Pozycja ludu rozpatrywana była z punktu widzenia dobra państwa. Nawet jeśli w XVI wieku Andrzej Frycz Modrzewski dopominał się o prawa chłopów czy mieszczan, to miał na uwadze dobro Rzeczypospolitej: źle traktowany człowiek nie może dostatecznie identyfikować się z ojczyzną, nie może jej służyć. Odnajdujemy też narrację odwołującą się do wartości chrześcijańskich, do miłości bliźniego, z czego ma wynikać wstrzemięźliwość w relacjach z ludem. Jednak zawsze wartością nadrzędną jest państwo, jego wielkość, znaczenie. Dlatego też perspektywa badawcza Adama Leszczyńskiego jest godna uwagi, interesuje go bowiem odpowiedź na pytanie: jaka była sytuacja najniższych warstw społecznych w państwie i czy było to państwo tego ludu? Historia jako nauka o dziejach obarczona jest subiektywizmem w znacznie większym stopniu niż inne nauki, badacze wyciskają na niej swoje piętno. I jest to zrozumiałe, natomiast usilne próby pisania obiektywnej historii skazane są na niepowodzenie. Ponadto należy pamiętać, iż historia jako relacja o dziejach ma wiele znaczeń i realizuje się na różnych poziomach. Powołując się na autorytet Jerzego Topolskiego: granica między narracją naukową a potoczną nie jest wyraźna. Różne materiały mogą posłużyć do wydobywania wiedzy o przeszłości. Tak też jest w wypadku pracy Ludowa historia Polski, w której wykorzystano różnorodne materiały, poczynając od archiwaliów poprzez artykuły prasowe, opracowania naukowe $z$ wieków poprzednich i współczesne. Swoje miejsce mają w niej jednak także pisma pisarzy politycznych, publicystów czy działaczy społecznych. Nie można także pominąć literatury pięknej, której wykorzystanie jako egzemplifikacji kultury duchowej i intelektualnej danej epoki jest bardzo bliskie recenzentce, jednocześnie zaś jest uzasadnione w wypadku pracy, która koncentruje się na losie człowieka, nie zaś państwa czy narodu. Literatura piękna bierze pod uwagę to, co indywidualne i jednostkowe, nauka zaś poszukuje uogólnień i prawidłowości, rozpatruje zjawiska z per- 
spektywy dużych liczb. Wydaje się, że połączenie tych dwóch perspektyw daje pełniejszy obraz opisywanej rzeczywistości.

Jak czytamy, „Przeszłość jest polityczna i jest polityczną bronią” - to deklaracja, która daje sygnał także dla części środowiska politologicznego, zajmującego się historią myśli politycznej. Dlatego też recenzentka - politolog z wykształcenia (wychowanka pierwszego pokolenia polskich politologów, którzy byli z wykształcenia historykami) - dała sobie prawo do oceny pracy Ludowa historia Polski. W istocie jest to praca także politologiczna, zwłaszcza w tej części, w której opisywana jest geneza państwa Piastów. Z drugiej strony zrozumienie współczesnych mechanizmów życia społecznego i politycznego wymaga znajomości kontekstu historycznego. Wielowiekowe zniewolenie mas ludowych, pozbawienie ich podmiotowości, a często wręcz człowieczeństwa, skutkuje apatią i nieufnością wobec rządzących. Lektura Ludowej historii Polski uświadamia, że wiele postaw i zachowań współczesnych nie jest warunkowana tylko zaborami, okupacją czy życiem w systemie socjalistycznym. Wolnościowa historia Polski, którą lubimy epatować w Europie, staje się sloganem, gdyż była to wolność tylko wąskiej grupy uprzywilejowanych. Wspomniane $90 \%$ było tej wolności pozbawione, było skazane na arbitralną wolę osoby prywatnej, instytucja zaś państwa nie zapewniała żadnej ochrony, w związku z czym ta przytłaczająca większość przez całe wieki realizowała cele mniejszości. W tym momencie mógłby pojawić się zarzut pod adresem autora, iż idzie drogą marksistowskiego materializmu historycznego. Tak jednak nie jest, gdyż przez wszystkie wieki istnienia państwa polskiego, czy to w okresie feudalizmu, kapitalizmu czy socjalizmu, masy ludowe ciągle są instrumentem. Paradoksalnie nawet socjalizm tego nie zmienił, klasa robotnicza miała służyć socjalistycznej ojczyźnie. Można wysnuć uogólnienie, iż ciągle mamy do czynienia z sytuacją wykorzystywania ludu do wyższych celów.

Recenzowana praca może być inspiracją kolejnych badań w tym obszarze, jest także przyczynkiem do dyskusji nad zmianą paradygmatu w opisywaniu dziejów Polski. Rzetelna recenzja wymaga jednak, by wskazać także niedociągnięcia, których nie udało się autorowi uniknąć. Po pierwsze, nie zostały wyjaśnione cezury, określające narracje poszczególnych rozdziałów. Jest to szczególnie ważne, jeśli zważymy, że autor odchodzi od tradycyjnej chronologii dziejów Polski. Przyjęte ramy czasowe wymagają wyjaśnienia i uzasadnienia. Dla przykładu — rozdział III traktuje o czasach do 1520 roku, a dopiero w treści rozdziału pojawia się informacja o statucie toruńskim. Niestety nie odnajdujemy jednoznacznego wytłumaczenia, dlaczego ten dokument jest kluczowy w wyznaczeniu granic chronologicznych. Druga uwaga dotyczy nieco bezrefleksyjnego przytaczania opinii innych historyków. Na stronie 498 czytamy: „Ich poziom życia w porównaniu z dramatycznie trudnym okresem II RP zauważalnie więc wzrósł [...]. Wieś stać było także na kupowanie maszyn oraz towarów luksusowych [...]”. Cytat odnosi się do okresu okupacji i pozycji chłopów, a inspirowany jest pracą Jana T. Grossa. Jest to rażąco bezrefleksyjne przytaczanie opinii. Nie wnikając nawet w źródła historyczne, należy wziąć pod uwagę, że duża część ziem polskich została włączona do Rzeszy, gdzie pozycja polskiego chłopa została sprowadzona do roli siły roboczej i nie mogło być mowy o jakim- 
kolwiek bogaceniu się. Nastąpiła komasacja gospodarstw rolnych, których właścicielem byli Niemcy, co wynikało z założeń teorii „krwi i ziemi” Richarda Walthera Darre.

Autor stawia śmiałe hipotezy i jest to postępowanie badawczo twórcze, rozwijające naukę, dające asumpt do nowego podejścia. Jednakże zawsze istnieje wątpliwość, czy mamy dostateczną ilość materiału źródłowego, by je zweryfikować. Niektóre rozdziały pracy są bardzo udokumentowane, inne mniej. Poza tym lektura książki sprawia wrażenie ahistorycznego podejścia, racjonalizacji post factum z perspektywy człowieka XXI wieku. Inna uwaga krytyczna dotyczy umiejscowienia przypisów, które zostały umieszczone na końcu pracy. Takie usytuowanie bardzo utrudnia lekturę, a śledzenie źródeł $\mathrm{w}$ pracy naukowej ma kluczowe znaczenie.

Zasygnalizowane ułomności pracy nie umniejszają jej znaczenia. Recenzentka jest przekonana, iż jest to opracowanie ważne nie tylko w obszarze nauk historycznych. Jest to książka, którą należy brać pod uwagę, gdyż jest ona pewnego rodzaju kontrapunktem odnośnie do innych opracowań. Jakkolwiek dla niektórych badaczy może być wręcz obrazoburcza, jako że demitologizuje przeszłość Polski, to przecież o to chodzi w nauce. Postęp i rozwój każdej z nauk wymaga zerwania z zastałym sposobem postrzegania rzeczywistości. Wymaga wymiany paradygmatu i nawet jeśli w tych działaniach popełniamy błędy, to zawsze mamy do czynienia z dobrem wnoszonym do nauki. Tak też traktuję recenzowaną pracę Ludowa historia Polski. 